\title{
PLATÃO: CRÍtica E CENSURA A POESIA
}

\author{
Luciano da Silva Façanha ${ }^{1}$ \\ José Assunção Fernandes Leite ${ }^{2}$ \\ Eliete da Silva $\mathrm{Cruz}^{3}$ \\ Universidade Federal do Maranhão (UFMA) \\ D https://orcid.org/0000-0003-4101-4364
}

\begin{abstract}
RESUMO:
O presente artigo tem como objetivo abordar a questão sobre a natureza da arte, em específico da poesia trágica, seus efeitos sobre os indivíduos e a censura da poesia, segundo a concepção de Platão na obra República, especificamente nos livros II, III e X. Na República, Platão ao censurar, condenar e rejeitar a poesia como um instrumento para a formação dos indivíduos, vai de encontro ao modelo tradicional grego de educação. Sua crítica adentra na tradição de seu povo. Essa postura platônica é pautada sobre o estudo da natureza da poesia, a mímesis, e sobre os efeitos da poesia nos indivíduos. Desse modo, primeiramente apresenta-se a concepção de Platão sobre a poesia, abordando o conceito de mímesis, em seguida a censura platônica a poesia, e algumas considerações.
\end{abstract}

PALAVRAS-CHAVES: Arte; Poesia; Mímesis.

\section{PLATÃO: CRITICISM AND CENSURE THE POETRY}

\begin{abstract}
The presente article is aimed at addressing the issue about the nature of art, particularly the tragic poetry, its effects on individuals and the censorship of the poetry, according to Plato's conception in Republic, more specifically in books II, III and X. In the Republic Plato goes against the traditional Greek model of education when he censors, condemns and

\footnotetext{
${ }^{1}$ Doutor em Filosofia pela Pontifícia Universidade Católica de São Paulo (PUC/SP), São Paulo - Brasil, professor do Departamento de Filosofia e do Programa de Pós-Graduação em Cultura e Sociedade da Universidade Federal do Maranhão ( UFMA), Maranhão Brasil. E-mail: lucianosfacanha@ @otmail.com

${ }^{2}$ Doutor em Filosofia pela Pontifícia Universidade Católica de São Paulo (PUC/SP), São Paulo - Brasil, professor do Departamento de Filosofia da Universidade Federal do Maranhão (UFMA), Maranhão - Brasil. E-mail: jfakenaton@uol.com.br

${ }^{3}$ Mestranda do Programa de Pós-Graduação em Cultura e Sociedade (PGCult) - Mestrado Interdisciplinar da Universidade Federal do Maranhão ( UFMA), Maranhão - Brasil. Email: eliete_219@hotmail.com
} 
rejects poetry as an instrument for individuals' formation. His criticism enters the tradition of his people. This platonic attitude is guided on the poetry's study nature, mimesis, and the effects of poetry on individuals. Thus, at first we presente Plato's conception on poetry, addressing the mimesis concept, the platonic censorship to poetry, and some considerations.

KEYWORDS: Art; Poetry; Mimesis.

\section{Introdução}

Nietzsche, em sua famosa obra Die Geburt der Tragödie oder Griechentum und Pessimismus - comumente traduzida em português por $O$ Nascimento da Tragédia ou Helenismo e Pessimismo, afirma que os gregos tinham uma propensão intelectual particular para "o duro, o horrendo, o mal, o problemático da existência" e que por conta disso criaram uma das maiores expressões artísticas humanas: o teatro trágico ou, simplesmente, a tragédia (NITEZSCHE, 1992, p. 14).

Nos dias atuais, quando pensamos sobre uma tragédia grega, é comum tomá-la como um livro sobre o qual nos debruçamos intelectualmente com o objetivo de extrairmos dele alguma compreensão sobre como os gregos sentiam o trágico em suas vidas e como o expressavam artisticamente.

Essa tem sido a principal abordagem ao longo desses últimos séculos e foi dessa maneira que a civilização ocidental incorporou e transformou essa singular forma artística criada pelos gregos. No entanto, é claro que não era assim para os próprios gregos. E mesmo quando temos a oportunidade de assistir a encenação teatral de uma tragédia grega, o que vemos em cena certamente ainda está muito distante da forma como era experimentado o fenômeno trágico em Atenas no séc. V a.C.

Conforme os autores Jean-Pierre Vernant e Pierre Vidal- Naquet (2005, p.2), "a tragédia grega aparece como um momento histórico delimitado e datado com precisão. Vêmo-la nascer em Atenas, aí florescer e degenerar quase no espaço de um século". Seu momento de maior relevo deu-se no século V a.C., época de Sófocles, Ésquilo e Eurípedes.

De acordo com o estudioso brasileiro Junito de Souza Brandão, no início de seu livro - Teatro grego: tragédia e comédia - a tragédia grega tem origem no culto de Dionísio ${ }^{4}$ — o deus do vinho, da alegria, da exuberância, das potências geradoras e "da excitação de toda espécie e da união mística” (HEINZ-MOHR, 1994, p.173).

\footnotetext{
4 Para o estudioso, "isto, apesar de algumas tentativas, ainda não se conseguiu negar" (BRANDÃO, 1996, p.9).
} 
Seguindo a análise de Junito de Souza Brandão a palavra "tragédia" provavelmente derivou-se de tragoidia, um vocábulo formado a partir de dois outros: trágos, que se traduz por "bode", e oidé, que quer dizer "canto". Desse modo, etimologicamente, tragédia significa "canto do bode". Segundo uma das interpretações que procuram explicar a causa dessa origem, conta-se que Dioniso, em Ícaro, havia ensinado aos homens, pela primeira vez, a arte de cultivar vinhas. Assim que as videiras cresceram, um bode, acusado de tê-las destruído, fora castigado com a morte. Após persegui-lo e esquartejá-lo, os homens, sobre a sua pele, começaram a dançar e a beber até caírem desmaiados.

Tudo indica que esse acontecimento passou a fazer parte dos rituais dionisíacos e a ser rememorado anualmente. Isso porque, durante os festivais, após um bode ser oferecido a Dioniso, cantava-se e dançava-se até a exaustão. Tais cantores e dançarinos travestiam-se em "sátiros, que eram concebidos pela imaginação popular como 'homens-bodes"” (BRANDÃO, 1996, p.10).

Dentre os vários tipos de cantos que eram apresentados nas celebrações dionisíacas, destaca-se o ditirambo — um canto lírico, ao mesmo tempo alegre e doloroso, que narrava os momentos tristes da passagem de Dioniso pelo mundo mortal e seu posterior desaparecimento e que, graças à forma exuberante com que exprimia a saga do deus, podia levar os ouvintes ao êxtase. Este canto em coro acabou se definindo como trágico e dele nasceu a tragédia: "representação viva feita por atores que narrava os fatos acontecidos no plano mítico e que, problematizando a situação do herói, discutia os valores fundamentais da existência humana" (SANTOS, 2006, p.43).

Comentando sobre o vínculo da cidade com a tragédia, Jean-Pierre Vernant e Pierre Vidal- Naquet (2005, p.10) afirmam que:

\begin{abstract}
A tragédia não é apenas uma forma de arte, é uma instituição social que, pela fundação dos concursos trágicos, a cidade coloca ao lado de seus órgãos políticos e judiciários. Instaurado sob a autoridade do arconte epônimo, no mesmo espaço urbano e segundo as mesmas normas institucionais que regem as assembléias ou tribunais populares, um espetáculo aberto a todos os cidadãos, dirigido, desempenhado, julgado por representantes qualificados das diversas tribos, a cidade se faz teatro, ela se toma, de certo modo, como objeto de representação e se desempenha a si própria diante do público.
\end{abstract}

Enquanto gênero literário, a tragédia aparece como expressão de um tipo particular de expressão humana, ligada a condições sociais e psicológicas definidas (VERNANT; NAQUET, 2005, p.7). É composta por regras e características próprias, são impregnadas por pré-supostos, préconceitos, estabelecendo-se assim como quadros de vivência cotidiana para a civilização de que elas são uma das expressões. Nesse sentido, o gênero 
dramático caracteriza-se como um fenômeno cujas dimensões social, estética e psicológica são indissolúveis, isto é, se articula para constituir um feito humano único, uma nova invenção.

O quê a tragédia expõe é o duelo entre duas diké - um conflito entre uma personagem e algum poder de instância maior, como a lei, os deuses, o destino (moira) ou a sociedade. Nesse conflito trágico, não compete aos personagens (herói, rei e tirano) a solução do drama. Além do mais, a solução reflete os valores coletivos. Nesta perspectiva, Jean-Pierre Vernant e Pierre Vidal- Naquet $(2005$, p. XXI) afirma que no conflito trágico, o herói, o rei e o tirano ainda aparecem presos a tradição mítica, mas a solução do drama escapa a eles: jamais é dada pelo herói solitário e traduz sempre o triunfo dos valores coletivos impostos pela nova cidade democrática. O universo trágico é formado por uma tríade, a saber, a esfera mítica, a heróica e o âmbito dos valores humanos - valores coletivos da sociedade a qual o drama é expressão. Cabe ressaltar que a tragédia dirigi-se à esfera das paixões e ações humanas.

Esse breve resumo sobre a tragédia já nos ajuda a circunscrever um pouco mais precisamente o contexto sócio-político-religioso onde a tragédia, enquanto expressão artística, se estabelece. Diante do que foi exposto, não espanta que um dos filósofos gregos mais representativos, Platão, tenha se ocupado em analisar sua natureza e sua função educativa, dirigindo a investigação filosófica, pela primeira vez, aos problemas relativos à tragédia e também à arte de forma geral.

Nesse sentido, a primeira coisa a se ressaltar é que, etimologicamente, o termo arte exprime o ars dos latinos, que por sua vez traduz a palavra grega téchne. De forma geral, téchne significava, para os gregos, o que é ordenado ou toda espécie de atividade humana submetida a regras $^{5}$. De forma que, na Antiguidade, o conceito de arte compreendia um âmbito bem mais amplo que o atual, e incluía além de artesanato e das "belas artes", qualquer tipo de atividade dirigida por um conjunto de regras, fazendo com que os gregos pudessem falar, entre outras, de uma arte bélica, de uma arte médica, de uma arte política, de uma arte retórica e de uma arte poética, pois o exercício destas atividades assenta-se sobre a ideia de regras e conhecimentos específicos.

Nesse contexto, a téchne enquanto ofício, habilidade para fabricar, construir ou compor algo, liga-se a poíeses - ação de fabricar, fabricação, composição de uma obra poética.

É Platão quem inaugura a teorização filosófica sobre a arte $^{6}$, tanto em seu sentido mais geral quanto em seu sentido mais estrito, isto é, enquanto artesanato e "belas artes". Teorização essa que, em relação ao

\footnotetext{
${ }^{5}$ Aqui, adotamos a conceituação de arte conforme apresentada no Dicionário de Filosofia do autor Nicola Abbagnano.

${ }^{6}$ Aqui, usamos o termo arte não como tradução da téchne dos gregos, mas na sua acepção moderna, ou seja, como "belas artes".
} 
segundo aspecto, perpassará toda a história da estética, com conseqüências importantes para as teorias da história e da crítica da arte, uma vez que Platão exclui a poíesis artística da esfera dos procedimentos com estatuto epistemológico verdadeiro e seus produtos da esfera dos seres com estatuto ontológico real.

Nesse momento inicial, em que a arte é tratada sob a perspectiva de uma "poética" - arte produtiva e arte produtiva de imagem (PLATÃO, 1972, 265a) - o cerne da investigação filosófica são os seguintes problemas: a relação entre arte e natureza, a relação entre arte e homem e as finalidades ou funções da $\operatorname{arte}^{7}$. No que concerne a relação entre "arte e natureza" (ou, em geral, a realidade), na qual a arte é entendida como algo dependente da natureza, temos a concepção de "arte como imitação". Em Platão, encontramos a concepção de arte como imitação. A passividade da imitação artística, o pintor só reproduz a partir do objeto construído pelo artesão e o poeta só copia a aparência dos homens e de suas atividades, sem perceber-se realmente das coisas que imita e sem a capacidade de realizá-las (PLATÃO, 2006, 598b; 599b).

Conforme veremos, Platão não escreveu nenhum Diálogo no qual aborde a poesia trágica de forma direta. No entanto, Platão desenvolve uma crítica a esta "manifestação artística" a partir de um âmbito maior - a poesia ${ }^{8}$. Vale ressaltar o valor educacional desta poesia. A educação grega tradicional estava assentada na ginástica e na poesia. Nesse contexto, Platão elabora sua crítica à poesia tendo como parâmetro a essência desta atividade e de seus efeitos.

Platão (2006, 598b), em conformidade com o plano educativo para a cidade ideal e como consequencia de sua Teoria das Ideias, censura as imitações de tudo que não for perfeito, declarando a mímesis como algo distante da verdade, pois está três graus afastada da natureza. A partir disto, a poesia, devido a sua natureza mimética, é rebaixada a categoria de "ilusão" e, por seus, indesejáveis efeitos psicológicos, torna-se inadmissível na cidade idealizada por Platão. Nesse contexto, encontra-se a comédia e a tragédia, visto que ambos os gêneros, consoante a concepção platônica, são uma espécie de poesia e de ficção inteiramente imitativa cujo objeto de imitação é a aparência da virtude e dos outros temas que tratam. Desprovida de verdade, a tragédia possui implicações não desejáveis na vida dos indivíduos, pois o espectador torna-se mais suscetível a experimentar as emoções representadas e, atingido pelos efeitos provocados pela contemplação do sofrimento alheio, tende a enfraquecer o controle da razão em relação às partes inferiores da alma (PLATÃO, 2006, 606b).

\section{A arte poética}

\footnotetext{
${ }^{7}$ A respeito vide Abbgnano, Dicionário de Filosofia, 2003, p.367 (estética).

${ }^{8}$ A Epopéia, a Poesia Ditirâmbica, a Comédia e a Tragédia são manifestações da poesia ou arte poética. $C f$. A República (394b-c).
} 
Como se sabe, Platão não escreveu nenhum Diálogo cuja temática central fosse a tragédia ou o gênero trágico. A crítica platônica a essa expressão artística se desenvolve no interior de uma discussão mais ampla sobre a poesia em geral, na qual a tragédia é tomada apenas como uma de suas espécies. Nesse sentido, o locus classicus platônico são as passagens encontradas nos Livros II e III de A República, consideradas, tradicionalmente, o momento inaugural de teorização da arte na história do pensamento ocidental.

O primeiro ponto fundamental a se considerar, na análise da crítica platônica, é a perspectiva em que essa crítica se dá. Nesse sentido, deve-se sublinhar, antes de qualquer coisa, que a idéia de uma arte autônoma, isto é, deslindada de instâncias extra-estéticas tal como a concebemos atualmente, é totalmente estranha a Platão. De saída, o fato desse testemunho se encontrar num diálogo chamado A República cuja proposta é investigar a natureza da justiça e que seu desenvolvimento se dê em meio a uma discussão sobre a forma adequada de se educar os futuros guardiães de sua cidade ideal já sugere o quão distante Platão se encontra de uma percepção do fenômeno estético orientada para a sua especificidade e independência.

$\mathrm{O}$ segundo ponto fundamental diz respeito ao fato de que o conceito de arte (téchne) na Antiguidade Clássica compreendia um âmbito bem mais amplo do que conhecemos atualmente e designava tudo àquilo que é ordenado por regras, ou melhor, todo conjunto de regras que ordena uma atividade humana qualquer, fazendo parte, assim, não do que hoje designamos por estética, mas do domínio da poética (poietiké) e constituíase como uma espécie de "produção" ou "fabricação" (poíesis). Nesse sentido, Platão e seus contemporâneos não diferenciavam a arte, no sentido em que hoje chamamos as belas-artes, das ciências nem da filosofia, uma vez que essas atividades assenta-se sobre a idéia de um conjunto de regras e conhecimentos específicos. Do mesmo modo, a guerra e a política (PLATÃO, 1970, 322a) também são consideradas téchnes (artes), assim como a dialética, considerada por Platão a mais nobre das poesias (PLATÃO, 1972, 266d).

No célebre diálogo intitulado $O$ Banquete, Platão aponta que a palavra poesia - tradução do termo poíesis - possui, em sua acepção originária, o sentido de "fabricação em geral".

Diotima - Como o seguinte. Sabes que a "poesia" é algo de múltiplo; pois toda causa de qualquer coisa passar do não-ser ao ser é "poesia", de modo que as confecções de todas as artes são "poesias", e todos os seus artesãos poetas.

Sócrates - É verdade o que dizes.

Diotima - Todavia - continuou ela - tu sabes que estes não são denominados poetas, mas têm outros nomes, enquanto que de toda a "poesia" uma única parcela foi destacada, a que se refere à música e aos versos, e com o nome de todo é denominada. 
Poesia é com efeito só isso que se chama, e os que tem essa parte da poesia, poetas (PLATÃO, 1972, 205b-c).

Por outro lado, podemos dizer que a poesia (poíesis) distingue-se, no seu complexo, entre atividades que visam comover a alma, a exemplo da música, da poesia, do teatro, e atividades tais como artesanato, cerâmica, tecelagem e ourivesaria, distinção que será retomada mais tarde pelos latinos, entre artes liberales e artes serviles (BOSI, 1995, p.14).

Entretanto, quaisquer que seja o âmbito, a atividade designada pelo verbo poieo, do qual se origina a palavra poética, envolve segundo Platão, mímesis, termo que se traduz tradicionalmente por "imitação" e essa imitação é orientada por dois critérios, a saber, a forma ou ê̂dos a ser colocada na matéria e as regras ou preceitos de cada arte, por meio dos quais a matéria pode receber a forma que lhe foi determinada pela finalidade de seu uso. Com relação ao primeiro critério, a forma ou eidos teria o papel de modelo ou paradigma que guia e orienta o trabalho do técnico/artesão conferindo assim uma orientação objetiva ${ }^{9}$ a essa atividade.

A partir desta concepção, Platão acusa os poetas de não seguirem os preceitos corretos quando executam sua atividade e os acusa de serem desprovidos de conhecimento sobre o paradigma (forma ou eîdos) que deve orientar sua atividade e sobre aquilo a que se propõe a falar. Esta censura platônica à atividade dos poetas será abordada no tópico seguinte.

\section{A crítica à poesia}

O tema central do diálogo platônico A República é, como se disse, a investigação sobre o conceito de justiça. E a primeira coisa que chama a atenção são as inúmeras referências e citações aos poetas encontrados nos três primeiros livros da obra, entre as quais se destacam a referência ao poeta Simônides, presente na definição sobre justiça proposta por Céfalo e Polemarco e a análise realizada por Sócrates da definição extraída de Homero (PLATÃO, 2006, 331e; 334b). Todas essas passagens põem em relevo a enorme influência e o papel dos poetas na educação helênica.

A concepção do poeta para os gregos era diferente da que temos atualmente. Os gregos aprendiam a ler e escrever nas obras dos poetas. $\mathrm{O}$ próprio Platão (2006, 599c-d) afirma, segundo opinião geral no seu tempo, ter sido Homero o educador de toda a Grécia. Sob esta perspectiva, W. Jaeger (2001, p.61) nos informa que a concepção do poeta como educador do seu povo - no sentido mais amplo e profundo da palavra - foi familiar aos gregos desde a sua origem e manteve sempre a sua importância, sendo

\footnotetext{
${ }^{9}$ Esta orientação objetiva equivale dizer que a poiésis do artesão/técnico não parte do nada ou de sua subjetividade, mas de algo pressuposto ou preestabelecido. A respeito vide A República (377e; 379a e 596b).
} 
Homero o exemplo mais notável desta concepção geral e, por assim dizer, a sua manifestação clássica.

De modo que a poesia figurava como pedra fundamental no modelo tradicional de educação grega. Modelo este que consistia em educar os indivíduos desde a mais tenra idade com a leitura dos poetas a fim de que os valores, conselhos, atos, etc., expostos em tais obras e considerados exemplares fossem aprendidos e imitados por eles.

Os mestres cuidam das crianças, e quando elas aprendem as letras e estão prontas parar compreender a escrita tal como antes a fala, eles as colocam sentadas nos bancos a ler os poemas dos bons poetas e as obrigam a decorá-los, nos quais inúmeras admoestações, inúmeras exposições, elogios, e encômios aos antigos bons homens, a fim de que a criança, tendo apreço por eles, os imite e aspire tornar-se-lhes semelhante (PLATÃO, 1970, 325e-326a).

Nesse contexto, a função educativa da poesia se estabelece devido ao seu conteúdo normativo e ao seu aspecto ético. No entanto, conforme W. Jaeger (2003, p.63), a poesia só pode ser propriamente educativa se suas raízes adentrarem nas camadas mais profundas do ser humano e na qual viva um Ethos, um anseio espiritual, uma imagem do humano capaz de tornar uma obrigação e um dever. E é justamente nesse aspecto, no interior de uma Paidéia, que Platão, em sua obra A República, critica a atividade do poeta.

- Logo, para uma porção de coisas, não exijamos contas a Homero, nem a qualquer outro poeta (...). Mas sobre os temas mais importantes e mais belos que Homero empreende tratar, sobre as guerras, o comando dos exércitos, a administração da cidade, a educação do homem, é talvez justo interrogá-lo (...) (PLATÃO, 2006, 599c-d).

Nos livros II e III, em A República, a poesia (mythos), entendida como mitos ou as histórias narradas sobre os deuses, é abordada no contexto da educação musical ${ }^{10}$, primeira etapa do programa educativo, dos guardiões da cidade idealizada por Platão. Estes homens comporão a classe que deverá receber a melhor educação, visto que são responsáveis pela proteção da politéia, de modo que deverão no que tange ao corpo, ser dotados de qualidades físicas como a rapidez, força, coragem e sentidos aguçados, e, no que tange a alma, de uma natureza filosófica a fim de serem brandos para com os amigos e rudes para com os inimigos (PLATÃO, 2006, 375a-e).

\footnotetext{
${ }^{10}$ Essa educação musical é descrita por Nickolas Pappas como todas as atividades tuteladas pelas musas, isto é, a dança, a astronomia, a história e a todos os tipos de poesia. Dentre estas atividades, Sócrates escolhe a poesia como minucioso exame; sendo neste caso que as observações sobre a educação se tornam parte de uma crítica mais ampla da cultura grega.
} 
Nesse contexto, a crítica platônica é estabelecida a partir de três aspectos: "o conteúdo acerca dos deuses", "os efeitos psicológicos da poesia - corrupção da alma" e "a essência da poesia - a imitação poética como um processo intrinsecamente ignorante".

No que se refere ao primeiro ponto, isto é, às narrativas sobre os deuses encontrados nos mitos tradicionais, a objeção de Platão é de ordem moral. Platão $(2006,378 b)$ demonstra que estes mitos representam negativamente tais divindades e assim, propõem aos jovens, modelos de comportamentos iníquos e que, portanto, não adequados à formação exigida aos guardiões. Mais precisamente, tais mitos encerram em si mentiras, não apresentando, nem sequer alegoricamente, os deuses como aquilo que podemos provar ser verdadeiro acerca deles (2006, 377d-e,379a). Nesta perspectiva, se se tem como objetivo inculcar nos jovens cidadãos modelos corretos de comportamentos é necessário, consoante a censura feita por Platão, que os discursos poéticos não mostrem atos imorais entre os deuses, nem os apresentem como divindades causadoras tanto do bem quanto do mal; como divindades que promovem o sofrimento injustificado, que mentem e que mudam de aparência.

\footnotetext{
Cumpre ainda evitar absolutamente - continuei - dizer que os deuses fazem guerras aos deuses, estendem-se armadilhas uns aos outros e combatem entre si, mesmo porque isso não é verdade se quisermos que os futuros guardiães de nossa cidade considerem o cúmulo da vergonha brigar entre si levianamente.

$[\ldots]$

E Deus é absolutamente simples e verdadeiro, em ato e em palavra; não muda por si próprio de forma e não engana os outros por fantasmas, nem por discursos, nem pelo envio de sinais, no estado de vigília ou em sonho (PLATÃO, 2006, $378 \mathrm{c}-\mathrm{d} ; 382 \mathrm{e})$
}

Pois se a poesia possui uma função pedagógica, exercendo assim influência sobre as ações humanas, então é necessário que o discurso poético esteja submetido a modelos convenientes ou apropriado. Nesse sentido, a crítica platônica concentra-se no fato de que os poetas não seguem o "modelo" apropriado em suas imitações (mímesis). Sendo assim, Platão (2006, 380c; 383a) não somente censura a atividade dos poetas como prescreve regulamentos para a composição poética, isto é, apresenta os modelos convenientes aos quais os poetas devem submeter-se em suas composições referentes aos deuses, a saber: 1 - Deus é somente a causa do bem e 2 - a sua imutabilidade - não mudam de forma e não nos extravia por meio de embustes, em palavra ou em ato.

Vale ressaltar que, com o objetivo de proteger os "seres desprovidos de razão e as crianças" (2006, 378a), a cidade inteira deve modificar o uso da poesia. Conforme Platão, "o menor número possível" deverá saber, por 
exemplo, que Cronos castrou o pai $\left(2006,378\right.$ a) ${ }^{11}$, que ninguém, "seja novo ou velho", poderá ouvir dizer que um deus é causador de mal e que as mães deverão ignorar as histórias referentes aos deuses que mudam de aparência, de modo a não as fazerem passar para os filhos (2006, 380b-c; 381e).

Exposta a crítica ao conteúdo pedagógico da poesia, Platão passa a tratar da dimensão psicológica desta atividade. É neste contexto que encontramos referências mais precisas e diretas à comédia e à tragédia enquanto expressões poéticas. Platão $(2006,394 c)$ as define como uma "espécie de poesia e de ficção inteiramente imitativa" a qual tem como um de seus objetos de imitação as aparências da virtude.

Em referência ao gênero trágico, Platão assenta sua crítica, mais precisamente, em dois pontos: 1) os efeitos dirigidos sobre o estado emocional do espectador e 2) a vulnerabilidade das ações a que o indivíduo está suscetível após experimentar as emoções apresentadas. Conforme Platão, os indivíduos tornam-se mais suscetíveis a experimentar, em situações particulares, as emoções apresentadas neste tipo de drama, assim como tem seu estado emocional afetado pelos efeitos oriundos da admiração do sofrimento alheio, acarretando assim, a debilidade do controle da razão sobre as partes inferiores da alma ${ }^{12}$.

- Se consideras que o elemento da alma que em nossos próprios infortúnios, contemos a força, que tem sede de lágrimas e gostaria de saciar-se à vontade com lamúrias, pois está em sua natureza desejá-las, é precisamente aqueles que os poetas se dedicam a satisfazer e a rejubilar; e que, de outro lado, o melhor elemento em nós mesmos, não sendo suficientemente formado pela razão e pelo hábito, relaxa o seu papel de guardião para com este elemento atreito às lamentações, a pretexto de ser erro espectador das desgraças de outrem, de não haver para ele vergonha, se um outro, que se diz homem de bem, derrama lágrimas fora de propósito, em louvá-lo e compadecê-lo, de julgar este seu prazer um lucro do qual não suportaria privar-se menosprezando a obra toda. Pois a poucas pessoas é dado, imagino, fazer a reflexão de que o que experimentamos a propósito das desventuras alheias, experimentamos a propósito das nossas próprias desventuras; tanto mais que, após nutrir a nossa sensibilidade com esse

\footnotetext{
${ }^{11}$ Hesíodo, Teogonia, vv. 154 - 181. Nesse trecho do poema, Hesíodo conta como Urano, que ocultava os filhos nas profundezas da Terra, foi castrado e destronado por Cronos. $C f$. nota 32 do Livro II, A República.

12 Consoante Platão, três são as partes da alma, a saber, o "elemento racional" pelo qual a alma raciocina e domina os impulsos corpóreos, o "elemento irracional e apetitivo" que preside aos impulsos, aos desejos, às necessidades e concerne ao corpo, e ao "elemento irascível" que é aliado ao principio racional e indigna-se e luta por aquilo que a razão julga justo neste aspecto. Considerando a relação hierárquica das referidas espécies, vislumbra-se a educação da alma que corresponde a ordenação interna de cada faculdade $(C f$. Rep.II,439d-440.Vê supra N.43,P.168; N.52, P.171).
} 
infortúnios, não é fácil conte-la nos nossos (PLATÃO, 2006, 606b).

As partes da alma possuem uma relação hierárquica, "segundo a qual a parte racional, tendo como aliada a parte irascível, deve conter e comandar as afecções da parte apetitiva". No entanto, conforme a análise elaborada por Platão, a poesia, e mais precisamente a tragédia, não contribui para essa educação da alma que visa uma ordenação interna, ao contrário, a poesia corrompe essa ordenação interna, logo o motivo de censurá-la.

O alvo da crítica platônica fica mais claro quando ele passa a analisar as características formais da poesia. Platão afirma que três são as formas de poesias: a simples narrativa na qual o poeta relata por si seu ponto de vista; a dramática que é a pura representação e na qual o poeta se omite; e uma terceira, constituída pela mistura das duas anteriores. Dessa maneira, a simples narrativa caracteriza-se como um discurso em terceira pessoa ou uma "exposição", pois o enunciado revela seu autor, em contrapartida, a dramática é definida como discurso poético em primeira pessoa, no qual o "eu" do autor é alienado em detrimento de "outra instância, tida como real, e atrás da qual ele se esconde".

Mas ponhamos um fim quanto aos discursos; penso que, depois disso, cumpre examinar a dicção; teremos então tratado da maneira completa do fundo e da forma.

Então disse Adimanto: - Não compreendo o que queres dizer. É indispensável, todavia - repliquei. Talvez compreendas melhor da seguinte maneira. Tudo o que dizem os contadores dos mitos e os poetas não é relato de acontecimentos passados, presentes ou futuros?

Como - respondeu ele - seria diferente?

Pois bem! Não empregam para tanto o relato simples, ou imitativo, ou ambos a um só tempo?

Disso também te peço uma explicação mais clara.

Sou, ao que parece, um mestre ridículo e obscuro. Portanto, como os que são incapazes de se explicar, não tomarei a questão no conjunto mas em uma das partes, e tentarei por aí mostrar-te o que quero dizer. Responde-me: não sabes os primeiros versos da Ilíada, onde o poeta narra que Crises pediu a Agamênon que lhe devolvesse a filha, por ele raptada, e que o sacerdote, não tendo logrado o objeto de seu pedido, invocou o deus contra os aqueus?

Sei, sim

Sabes portanto que até estes versos: "Ele implorava a todos os aqueus, mas sobretudo aos dois Atridas, chefes de povos", o poeta fala em seu nome e não procura voltar nosso pensamento em outro sentido, como se fosse outro o autor destas palavras e não ele próprio. Mas no que segue, ele se expressa como se fora Crises e se esforça por nos dar na medida do possível a ilusão de que não é Homero quem fala, mas o ancião, o sacerdote de Apolo: e, quase da mesma maneira compôs ele 
todo o relato dos acontecimentos que se sucederam em Ílio, em

Ítaca e em toda Odisséia.

Perfeitamente - disse ele.

Há narração, portanto, em ambos os casos: tanto na reprodução dos discursos pronunciados pelas personagens, como quando relata os eventos que se colocam estes discursos?

Como não?

Mas quando fala sob o nome de outrem, não diremos que torna na medida do possível a sua elocução semelhante à da personagem cujo discurso ele nos anuncia?

É o que diremos. Por que não?

Ora, tornamo-nos semelhante a outrem com respeito à voz e ao aspecto, é imitar aquele ao qual nos tornamos semelhantes?

Sem dúvida (PLATÃO, 2006, 392c-393c).

Nesta perspectiva, a poiésis do poeta abrange dois tipos de mímesis, a saber, a mímesis ao nível do lógos que envolve a relação "objeto-modelo" e "objeto-cópia"; e a mímesis ao nível da lexis, envolvendo a relação entre o "poeta" (sujeito) e o "objeto" do qual ele fabrica a "cópia". A primeira se dá em relação ao conteúdo - "o que é expresso no discurso" - e a segunda se dá em relação à forma - "maneira de expressar o conteúdo do discurso". De modo que a atividade do poeta define-se inteiramente como imitação (mímesis).

Além disso, o poeta, a fim de obter maior eficácia em seu discurso, utiliza-se de vários outros processos miméticos, a saber, a música e a dança. A música envolve três elementos, qual sejam o ritmo, a harmonia e o discurso. No entanto, a harmonia e o ritmo são determinados em função do conteúdo e da forma do discurso ao qual se ligam, visto que aqueles dois elementos não possuem nenhuma autonomia (2006, 398c-d).

Neste aspecto, a mímesis desenvolvida no discurso, ao nível do conteúdo e da forma, é repetida pela mímesis que envolve a harmonia e o ritmo. Tal como Platão (2006, 399a) aponta no seguinte exemplo:

- Não sou conhecedor de harmonia - confessei; - mas deixanos a que imita como convém, de um bravo empenhado na batalha ou em qualquer outra ação violenta, os tons e os acentos, quando por infortúnio, ele corre ao encontro de ferimentos, da morte, ou cai em qualquer outra desdita, e quando em todas estas conjeturas, firme em seu lugar e resoluto, repele os ataques da sorte. Deixa-nos outra harmonia para imitar o homem empenhado numa ação pacífica, não violenta, porém voluntária, que procura persuadir a fim de conseguir o que pede, seja a um deus com suas preces, seja a um homem com suas lições e conselhos, ou que, ao contrário, solicitado, ensinada, persuadido, se submete a outrem, e, tendo por estes meios realizado o seu fim, segundo a sua vontade, não concebe daí orgulho, mas conduz-se em todas estas circunstâncias com sabedoria e moderação, contente com o que lhe acontece. A estas duas harmonias, a violenta e a voluntária, 
que imitarão com maior beleza os acentos dos infelizes, dos felizes, dos sábios e dos bravos, a estas deixa ficar.

E ainda, a música e a dança, assentadas sobre a estrutura métrica do discurso, prolongam a imitação que se dá ao nível da fala em uma imitação ao nível dos atos. Logo, a mímesis realizada pela música e pela dança é uma imitação da imitação. Reiterando assim, a poesia como uma atividade puramente mimética.

O problema que Platão vê no modo de expressão poético é o seu potencial de gerar, ao nível do sujeito, "ilusão". Por envolver um sem número de processos miméticos, ele instaura tal confusão entre a realidade e o discurso, entre o "mesmo" e o "outro" que a linha que divide estes pólos tende simplesmente a desaparecer. Platão observa que, por este artifício, podemos nos exprimir de maneira a imitar não somente os discursos dos homens bons e justos, mas também dos injustos e vis, assim como os sons dos animais e os barulhos da natureza. E a coisa se complica ainda mais pelo fato de que estes procedimentos, quando utilizados pelo poeta, têm como objetivo suscitar, naqueles a quem se dirige, uma reação da mesma natureza da ação que a provoca, isto é, também uma imitação (2006, 395b; 397e).

A mímesis produzida pelos poetas estimula, portanto, o ouvinte a se identificar com a realidade à qual faz referência o discurso que ele escuta. A partir da "encenação" e dos demais recursos mencionados, a realidade evocada torna-se de tal forma presente ao ouvinte que a sua ausência efetiva é esquecida deslanchando um processo de identificação que modifica o comportamento físico e moral do ouvinte em questão. De modo que essa mímesis não é sem conseqüências, mas envolve questões com desdobramentos éticos evidentes. Como já dissemos, no tempo de Platão, fora das grandes festas cívicas e religiosas, a narração da poesia de Homero ou Hesíodo se dava principalmente entre as crianças constituindo junto com a ginástica a base da educação grega.

Mas o ponto principal da crítica de Platão à poesia e especificamente à tragédia é a sua análise daquilo que ele considera a essência da poesia: a mímesis; e se os dois primeiros pontos analisados anteriormente foram tomados sob o prisma moral, a análise da mímesis em sua essência se dá sob o ponto de vista epistemológico.

\section{Platão e a condenação da poesia}

A análise da mímesis, em sua essência, se encontra no Livro X de $A$ República. E se, inicialmente (Livros II e III), tratava-se apenas de censurar as narrativas míticas dos poetas, substituindo-as por modelos mais adequados, é aqui que encontramos a recusa em absoluto da poesia mimética em razão dessa ser vista como um processo intrinsecamente 
"ignorante", isto é, o poeta desconhece inteiramente aquilo que imita e a própria mímesis é incapaz de propiciar esse conhecimento.

Para explicar a natureza da mímesis, Platão, tendo como pano de fundo a sua célebre Teoria das Idéias, utiliza-se de uma analogia com a pintura, pois, assim como a poesia, ela é uma atividade que envolve mímesis, isto é, "imita" seus modelos. Conforme o filósofo existe a ideia de cama, única e essencial, da qual deus é criador; a cama particular produzida pelo artesão a partir da idéia de cama; e, finalmente, a cama do pintor que imita visualmente coisas particulares. Nesta perspectiva, o pintor de um objeto particular (objeto $\mathrm{X}$ ) não eleva seus olhos à Forma $\mathrm{X}$ deste objeto, contudo, voltando seus olhos somente às coisas individuais, dispostas no mundo sensível, só copia as aparências (PLATÃO, 2006, 596b). O pintor é ignorante da natureza das coisas.

\footnotetext{
- Agora, considera este ponto; qual desses dois objetivos se propõe a pintura relativamente a cada objeto: o de representar o que tal como é, ou o que parece tal como parece? É ela imitação da aparência ou da realidade?

- Da aparência - disse ele

- A imitação está, portanto, longe do verdadeiro, e se ela modela todos os objetos, é, segundo parece, porque toca apenas uma pequena parte cada um, a qual não é, alias, senão um simulacro (PLATÃO, 2006, 598b-c).
}

Eis assim a natureza da mímesis - algo distante do verdadeiro. Como dissemos acima, a analogia com a pintura se desenvolve tendo como pano de fundo a célebre Teoria das Idéias. Segundo essa teoria, a realidade é dividida em coisas sensíveis e coisas inteligíveis, sendo as últimas formas universais que seriam os arquétipos perfeitos das coisas particulares do mundo material. Desse modo, a relação entre o mundo sensível e o mundo inteligível é estabelecida por uma relação que Platão define ora como participação (metexis), ora como imitação (mímesis), na qual o sensível participaria do inteligível como cópia de um modelo ${ }^{13}$.

Nesta perspectiva, o conhecimento (episteme) caracteriza-se fundamentalmente pela apreensão das formas, ao passo que a mutabilidade do mundo cotidiano permite, na melhor das hipóteses, formular uma opinião $(\text { doxa })^{14}$. Logo, a "poesia" não levaria ao conhecimento, pois ela figura como uma imitação das coisas sensíveis ou dos acontecimentos que se desenrolam no mundo sensível, constituindo, antes, a recusa de se ultrapassar a aparência sensível em direção à verdadeira realidade.

\footnotetext{
13 Vide "méthexis" e "mímesis" em Termos filosóficos gregos: um léxico histórico (PETERS, 1977, p.143).

${ }^{14}$ Somente a Idéia ou o Ser mesmo das coisas pode ser a base do verdadeiro conhecimento, enquanto a opinião (doxa) se liga ao sensível e se funda nas aparências das coisas e não no que elas realmente são ( $A$ Rep.,476c).
} 
Consoante a reflexão platônica, portanto, o poeta não possui ciência nem opinião correta quanto à beleza ou aos vícios das coisas que imita, caracterizando-se, antes, como um fabricante de ilusão, autor de uma produção afastada em três graus da realidade (PLATÃO, 2006, 597e; 602a). Quanto aos que se ocupam de tragédia tem-se que são imitadores em supremo grau (PLATÃO, 2006, 602b). Nesta perspectiva, o comentador Nickolas Pappas nos afirma que a poesia mimética é ilusão e a relação desta com o conhecimento não somente se opõe, uma vez que o conhecimento caracteriza-se pela apreensão das formas universais que seriam os arquétipos perfeitos das coisas particulares, como se estabelece hierarquicamente, pois existe primeiramente a "idéia da coisa"; em seguida, "a coisa particular"; e, por último, "a representação artística" dessa coisa.

Em conformidade com o plano educativo para a cidade ideal e em consequiência de sua Teoria das Idéias, Platão, em A República, censura as imitações de tudo que não for perfeito, declarando a mímesis como algo distante da verdade, pois está três pontos afastados da natureza e assim, destituindo a poesia de qualquer elo com o conhecimento. Desse modo, Platão exclui a poesia da esfera dos procedimentos com estatuto epistemológico verdadeiro e seus produtos, a exemplo da tragédia, da esfera dos seres com estatuto ontológico real.

\section{Considerações finais}

Vimos que para Platão, a poesia é uma imitação (mímesis). Como já assinalamos anteriormente, para os gregos, a "arte" do poeta pertencia ao âmbito não do que hoje se denomina estética, mas da poética. Nesse aspecto, constituía-se como uma espécie de "fabricação" ou "produção" que envolveria certa orientação objetiva. Logo, a poíesis do poeta implicaria uma relação entre um "objeto-modelo" e um "objeto-cópia", definindo-se assim, como imitação (mímesis).

Em A República, Platão desenvolve uma "análise" sobre a tragédia a partir de um contexto maior, a saber, o âmbito da educação musical destinada aos guardiões da cidade ideal. Deve-se notar que para os gregos, a música era toda obra de arte tutelada pelas musas, a saber, a dança, a astronomia, a história e todos os tipos de poesia. Nesse contexto, a tragédia não se constituía como hoje concebemos - um excelente gênero literário com o qual nos debruçamos a admirar pela sua forma de escrita e interpretação. Para humanidade grega este tipo de poesia (tragédia) possuía cunho político, educacional e ético implicando em efeitos relevantes para a vida humana.

Como podemos entender após uma leitura da República, o tema da educação é extremamente importante. Sendo por meio deste tema que Platão analisa o papel pedagógico e os efeitos morais da poesia. Platão 
desenvolverá, inicialmente, sua crítica aos poetas e a poesia sob o ponto de vista moral.

$\mathrm{O}$ aspecto inicial de que Platão aborda a respeito da poesia (mythos) é o que concerne ao seu conteúdo, notadamente quanto à concepção dos deuses, ressaltando sua influência sobre as ações dos homens. Considerando que os discursos podem ser falsos ou verdadeiros, Platão enceta sua investigação pelos discursos com conteúdos falsos a respeito dos deuses e dos heróis. Consequentemente, Platão acusa os poetas de não dizerem a verdade (alétheia) acerca dos deuses, heróis e de quem quer que representem.

Nesse contexto, para reformar a pólis, Platão afirma ser necessária a reforma da poesia. Isto porque, "se quisermos dotar os guardiães da cidade ideal de qualidades úteis à cidade assim como de certa "natureza filosófica" é preciso que, desde a mais tenra idade, eles sejam educados segundo preceitos que reforcem estas qualidades e não com histórias que no mais das vezes não fazem outra coisa que estimular atitudes contrárias a elas" (PLATÃO, 2006, 376c-e).

Se as ações humanas são influenciadas pela poesia, então a composição poética não somente deve divulgar conteúdos que contribuam para a formação de bons cidadãos como deve está subjugada a determinados critérios. Os deuses jamais poderiam ser concebidos como seres injustos, adúlteros, vingativos ou ciumentos, pois se assim são representados, os jovens podem encontrar nestes modelos a justificação para os seus mais terríveis atos - "não se deve dizer diante de um jovem ouvinte que, praticando os piores crimes e castigando um pai injusto da forma mais cruel, ele nada faz de extraordinário e procede como os primeiros e maiores deuses" (PLATÃO, 2006, 378b). Desse modo, Platão prescreve regulamentos para a composição poética, ou seja, elenca modelos aos quais os poetas devem submeter-se ao "fabricar" suas poesias. Os discursos poéticos devem, primeiramente, mostrar deus não como causa de tudo, mas apenas do bem e ainda, os deuses não devem ser representados como mágicos que mudam de forma (PLATÃO, 2006, 380c; 383a).

Vale ressaltar que embora Platão censure as narrativas as quais retratem mentiras, ele aceita uma espécie de mentira a qual os governantes, somente estes, devam utilizar para beneficiar os governados. Eis assim a nobre mentira a qual os governantes têm acesso (PLATÃO, 2006, 459d). Nesse aspecto, a crítica platônica aos discursos poéticos, assentada sob a base da moral, parece um contra-senso. Ou ainda, Platão parece censurar não a mímesis, mas a forma imprópria como a mentira era efetuada nos discursos poéticos.

Nos livros II e III, a crítica platônica aos discursos poéticos implica uma limitação do uso da mímesis, ou seja, apenas para imitação dos exemplos dos homens de bem - os guardiões, especificamente, "não devem praticar nem saber imitar habilmente a baixeza, por medo de que, da 
imitação, venham encontrar prazer na realidade" (PLATÃO, 2006, 395c). Nesse aspecto, diante do projeto de reforma do governo dos homens, Platão (2006, 379a) reconhece o poder de persuasão da poesia como alternativa à violência, então deixa aberta a porta para o retorno dos poetas, desde que estes não se afastem dos modelos estabelecidos pela filosofia. Esta perspectiva reitera os efeitos psicológicos da poesia mimética nos indivíduos.

No entanto, se nos Livros II e III, a partir de uma perspectiva moral, a poesia mimética era parcialmente admitida, no Livro X ela será totalmente rejeitada. No último livro que compõe a República, não mais importa se os modelos pelos quais os poetas orientam seu trabalho são moralmente bons ou maus. Nesse momento, o fator preponderante é o estatuto ontológico e epistemológico da poesia.

Em A República (2006, 597d-e; 599a) Platão utiliza o paradigma da pintura para descrever a essência da poesia, a saber, a natureza da mímesis, e para descrever o quê seria o poeta. Tal como a pintura que por meio das formas e das cores representa certa realidade, a poesia, através das palavras, também representa uma realidade. A problemática nestas atividades é que a realidade representada, em si mesma, não está presente. Cabe lembrar que, para Platão, o real está dividido entre sensível e inteligível e a própria realidade sensível é uma imagem da realidade verdadeira, o mundo das idéias. Ainda mais, a realidade sensível não é perene e o conhecimento (episteme), conforme a Teoria das idéias, só é possível pela apreensão das formas universais - imutável e eterna. Nesse sentido, o pintor, ao realizar seu ofício, eleva seu olhar para o objeto existente no plano sensível e não para a idéia $\mathrm{X}$ deste objeto. Tal como o pintor é o poeta, ignorante sobre a essência daquilo que realizam, isto é, não contempla o arquétipo perfeito para realizar seu ofício.

A partir disso, pode-se afirmar que o fim (télos) tanto da pintura quanto da poesia seria, em última análise, realizar uma imitação que fizesse esquecer a ausência efetiva da realidade na qual se inspira dando a ilusão de sua presença. Neste sentido, o poeta - imitador que não possui ciência nem opinião reta quanto à beleza das coisas que imita (PLATÃO, 2006, 602a), obterá maior eficácia em seu discurso à proporção que utilizar variados recursos miméticos, isto é, na medida em que este discurso se fizer acompanhar de uma encenação, a partir de recursos visuais e orais, que corresponda ao que é narrado. A arte do poeta tem como desígnio fazer esquecer a ausência efetiva da realidade na qual ele se inspira.

Outro ponto a considerar sobre a análise de Platão à poesia, especificamente a tragédia, é a "experiência estética" - envolvimento emocional do espectador com a representação da tragédia. A partir desta concepção temos a afirmativa de que a poesia corrompe a razão. Para Platão (2006, 605b) o indivíduo fica vulnerável ao contemplar o sofrimento alheio - o domínio da razão é debilitado, pois a tragédia visa regozijar as partes 
inferiores da alma. Mais precisamente, o espectador pode experimentar as emoções apresentadas no drama e assim ser levado a agir, em situações particulares, motivados pelas paixões, ou seja, agir contrário as prescrições da razão.

A tragédia, além de ter o seu conteúdo comprometido, pois não apresentam os seres (deuses) tais como são, caracteriza-se como uma atividade mimética em supremo grau. Possivelmente pela natureza da mímesis e pelo fato de o drama se utilizar de outros recursos miméticos música, elocução, dança, etc. - que contribuem fortemente para maquiar a ausência de realidade a qual os poetas trágicos aludem. Nesse sentido, Platão $(2006,602 b)$ vê a imitação como uma espécie de jogo de criança, despido de seriedade e os poetas trágicos como imitadores em "supremo grau". Logo, a poesia é ilusão, sendo a tragédia uma "espécie de poesia e de ficção inteiramente imitativa", não podendo ser permitida em sua cidade ideal devido ao novo projeto político e educacional que faz essa cidade ser o quê é: uma cidade ideal.

Os indivíduos aprendem por imitação. É nesse aspecto que Platão fundamenta sua concepção política, pedagógica e psicológica para censurar e condenar a poesia.

\section{Referências bibliográficas}

ABBAGNANO, Nicola. Dicionário de filosofia. Tradução: Alfredo Bosi. $1^{\text {a }}$ ed. São Paulo: Martins Fontes, 2003.

BOSSI, Alfredo. Reflexões sobre a arte. $5^{\text {a }}$ ed. São Paulo: Ática, 1995.

BRANDÃO, Junito de Souza. Dicionário mítico-etmológico da mitologia grega. 2. vols. 4. ed. Petrópolis: Vozes, 2000.

Teatro grego: tragédia e comédia. 3. ed. Petrópolis: Vozes,

2000.

HEINZ-MOHR, Gerd. Dicionário dos símbolos: imagens e sinais da arte cristã. Tradução: João Rezende Costa. São Paulo: Paulus, 1994.

JAEGER, Werner. Paidéia: a formação do homem grego. Tradução: Artur M. Pereira. 4 ed. São Paulo: Martins Fontes, 2001.

NIETZSCHE, Friedrich Wihelm. O Nascimento da tragédia ou helenismo e pessimismo. Tradução: J. Guinsburg. São Paulo: Companhia da Letras, 1992.

PAPPAS, Nickolas. A república de Platão. Lisboa: Edições 70, 1995.

PETERS, F.E. Termos filosóficos gregos: um léxico histórico. Tradução: Beatriz Rodrigues Barbosa. 2 ed. Lisboa: Gulbenkian, 1983.

PLATÃO. Fédon. Tradução: José C. de S. e João C.C. São Paulo: Abril Cultura, 1983.

Protágoras. Tradução: Carlos Alberto Nunes. São Paulo: Melhoramentos, 1970. 
A república. Tradução: J. Guinsburg. São Paulo: Perspectiva, 2006. Sofista. Tradução: José C. de S. e João C.C. São Paulo: Abril Cultura, 1983.

O banquete. Tradução: José C. de S. e João C.C. São Paulo: Abril Cultura, 1983.

SANTOS, Adilson dos. A tragédia grega um estudo teórico. In: REVISTA LETRAS, Curitiba, N. 68, p. 41-67, Jan./Abr. 2006. Editora UFPR.

VERNANT, Jean-Pierre. Entre mito \& política. Tradução: Cristina Murachco. São Paulo: Editora da Universidade de São Paulo, 2001.

VERNANT, Jean P. e NAQUET, Pierre V. Mito e tragédia na Grécia antiga. Tradução: J. Guinsburg. 1. ed. São Paulo: Perspectiva, 2005.

\section{Contribuição dos autores:}

Os autores Luciano da Silva Façanha, José Assunção Fernandes Leite e Eliete da Silva Cruz participaram da discussão, revisão e redação do artigo. Todos os autores aprovaram a versão final do texto. 